\title{
CROWN MORPHOMETRIC INDEXES OF EUCALYPT ESTIMATED BY LOGISTIC REGRESSION AND SUPPORT VECTOR MACHINES
}

\author{
Bruno Oliveira Lafetá ${ }^{*}$, Rosália Nazareth Rosa Trindade², Vinicius Faúla Aguiar ${ }^{3}$, Tamires Mousslech Andrade \\ Penido $^{2}$, Diego dos Santos Vieira ${ }^{2}$
${ }^{1 *}$ Federal Institute of Education, Science and Technology of Minas Gerais, Department of Forest Engineering, São João Evangelista, Minas Gerais, Brazil - bruno.lafeta@ifmg.edu.br
${ }^{2}$ Federal University of the Jequitinhonha and Mucuri Valleys, Department of Forest Engineering, Diamantina, Minas Gerais, Brazil - rosalia_coluna@hotmail.com, penidotma@gmail.com, diegovieir4@gmail.com
${ }^{3}$ Federal Institute of Education, Science and Technology of Minas Gerais, Department of Agronomy, São João Evangelista, Minas Gerais, Brazil-vfaulaa@yahoo.com.br

Received for publication on: 01/03/2019 - Accepted for publication on: 17/06/2019

\begin{abstract}
Resumo
Índices morfométricos da copa de eucalipto estimados por regressão logística e máquinas vetor de suporte. A escolha adequada do método de modelagem para estimativas morfométricas da copa de árvores é importante para otimizar a mensuração e subsidiar a tomada de decisões silviculturais. O objetivo do presente trabalho foi avaliar a eficiência da modelagem de relações morfométricas interdimensionais da copa de eucalipto sob diferentes espaçamentos empregando regressão logística e Máquinas Vetor de Suporte (MVS). O experimento foi instalado com quatro espaçamentos (T1: 3,0 × 0,5 m; T2: 3,0 ×1,0 m; T3: 3,0 × 1,5 m e T4: 3,0 × 2,0 m). Realizou-se o inventário florestal contínuo nas idades de 24, 37, 48, 59 e 72 meses. Foram testados dois métodos de modelagem, um por regressão não linear (modelo logístico) e outro por MVS. Os índices de abrangência, saliência e de espaço vital decresceram com o aumento das dimensões do fuste das árvores, tendendo a uma estabilização. O modelo logístico se adequou satisfatoriamente aos problemas, mais especificadamente na predição dos dois primeiros índices. A modelagem por MVS usando a função Kernel de base radial pode ser usada com boa precisão para a estimativa de índices morfométricos da copa de eucalipto, simultaneamente, para diferentes espaçamentos de plantio.

Palavras-chave: Densidade de plantas; inteligência computacional; modelagem; regressão não linear.
\end{abstract}

\begin{abstract}
The proper choice of the modeling method for morphometric tree crown estimates is important to optimize measurement and support silvicultural decision-making. This study aims to evaluate the efficiency of interdimensional morphometric relationships modeling of eucalypt crown under different spacings using logistic regression and Support Vector Machines (SVM). The experiment was set up with four spacings (T1: $3.0 \times 0.5 \mathrm{~m} ; \mathrm{T} 2: 3.0 \times 1.0 \mathrm{~m} ; \mathrm{T} 3: 3.0 \times 1.5 \mathrm{~m}$ and T4: $3.0 \times 2.0 \mathrm{~m})$. A continuous forest inventory was carried out at the ages of $24,37,48,59$ and 72 months. Two modeling methods, one using nonlinear regression (logistic model) and the other using SVM, were tested. The range, salience and vital space indexes decreased with increasing tree stem dimensions, tending to stabilization. The logistic model was satisfactorily adapted to the problems, more specifically in prediction of the first two indexes. SVM modeling using radial base Kernel function can be used with good precision for crown morphometric indexes estimation of eucalypt, simultaneously, for different planting spacings.

Keywords: Plant density; computational intelligence; modeling; nonlinear regression.
\end{abstract}

\section{INTRODUCTION}

Planted area and productivity of commercial eucalypt plantations have grown since the 1970s, but there are still few companies that invest adequately in biometric modeling. Obtaining detailed knowledge of stands is a requirement that managers must pay attention to throughout the forest cycle (MELO et al., 2017). Information about crown morphometric indexes of trees improves targeting and adequacy of silvicultural practices, such as definition and plant density control, pruning, and harvesting (ROMAN et al., 2009; FEY et al., 2014; SILVA et al., 2017a).

Crown morphometric indexes and their interdimensional relations with stem allow for the reconstruction of the space occupied by the tree and to infer about its degree of competition, stability, and productivity (STERBA, 1991, SILVA et al., 2017a). The most popular morphometric indexes are crown formal, slenderness rate, range index, salience index, crown proportion, and vital space index (DURLO; DENARDI, 1998; SILVA et al., 2017a). Changes in crown and stem dimensions vary according to genotype and environmental conditions; larger spacing favors stem growth and lateral crown expansion (SEIDEL et al., 2016; CERQUEIRA et al., 2017).

FLORESTA, Curitiba, PR, v. 50, n. 3, p. 1633 - 1642, jul/set 2020.

Lafetá, B. O. et.al.

ISSN eletrônico 1982-4688

DOI: 10.5380/rf.v50 i3. 65255 
The surveying of all biometric data in a field can make forest inventories operationally unfeasible, since crown measurements are very time consuming and laborious (FEY et al., 2014). In this perspective, modeling appears as an alternative for indirect evaluation of morphometric indexes. Establishment of functional relationships for estimation of these indexes, using stem dimensions that correlate with the variable of interest, the reduced number of measured crown and optimizes mensuration (ROMAN et al., 2009; SILVA et al., 2017a). A current trend for application of crown metrics is in timber quantification with aerial photographs of high resolution and LiDAR technology (Light Detection and Ranging) (STABEN et al., 2016; HOLM et al., 2017).

Researches developed and published on inter-dimensional relationships of crown predominantly use linear regression models (ROMAN et al., 2009; FEY et al., 2014, DIONISIO et a1., 2017). Computational resources advancement and the search for mathematical models capable of describing reality with greater accuracy, have stimulated evolution and application of statistical methods in several areas of knowledge (CARVALHO et al., 2011; MELO et al., 2017). Among these methods, it is possible to mention the use of nonlinear regression models and computational intelligence.

Nonlinear regression models, such as logistics, have already been successfully tested in production modeling (CARVALHO et al., 2011), hypsometry, productive capacity classification (MELO et al., 2017) and assortments volume (MENDONÇA et al., 2014). The logistic model in its original form, with three parameters, has a horizontal asymptote, inflection point, and scale point (MELO et al., 2017). Sigmoidal behavior, biological basis and ease of parameters interpretation favor its use in the area of forestry. This facility is of great practical importance, providing conditions for a quick reliability analysis of estimates regarding convergence of the parameterization algorithm (MENDONÇA et al. 2014).

On the other hand, machine-learning techniques can solve complex problems and allow for modeling a system, with output and predictor variables knowledge, and with great capacity for generalization and processing time optimization (SILVA et al., 2017b). Although incipient in forest management systems, Support Vector Machines (SVM) contrast with artificial neural networks by the principle of minimizing structural risk of computational learning theory, which always converges to a global optimum (GHITESCU et al., 2017).

SVM method, developed by Vapnik (1995), is a supervised learning computational intelligence approach capable of solving pattern recognition and classification problems, regression and prediction (SILVA et al., 2017b). In addition to the advantage of knowledge independence and pressures on the relationships between adjustment variations, it allows for simultaneous simulations with use of numerical and strategic inputs in the same model.

The application of different statistical methods for biometric tree estimates relates to the fact that small improvements in accuracy represent significant gains in the total values at stand levels. In view of the above, the following hypotheses were tested: i) SVM are efficient for the estimation of crown morphometric indexes estimation and ii) logistic regression provides non-biased estimates of morphometric indexes. Therefore, this work is aimed to evaluate the interdimensional morphometric relationships modeling of eucalypt crowns under different spacings using logistic regression and SVM.

\section{MATERIAL AND METHODS}

\section{Experimental characterization}

This work was carried out at the Federal Institute of Education, Science and Technology of Minas Gerais - São João Evangelista campus, located at $18^{\circ} 32^{\prime} 52.55^{\prime \prime}$ south latitude and 4245'36.16" west longitude (Datum WGS84). The regional climate is Cwa type (temperate rainy-mesothermal), according to international Köppen system classification, with rainy summers and dry winters. Annual averages of precipitation and temperature are $1360 \mathrm{~mm}$ and $19.1^{\circ} \mathrm{C}$, respectively. Climatic data came from annual records from 1961 to 1990 , available in the database of the National Institute of Meteorology.

The experiment was set up in May 2012, using a hybrid of Eucalyptus grandis Hill ex Maiden x E. urophylla S. T. Blake, on a dystrophic Red-Yellow Latosol with prominent A horizon, sandy texture, and flat relief at an altitude of $710 \mathrm{~m}$ a.s.l. The experimental design comprised randomized three-blocks. Treatments consisted of four planting spacings (T1: $3.0 \times 0.5 \mathrm{~m}-1.5 \mathrm{~m}^{2}$ useful area; $\mathrm{T} 2: 3.0 \times 1.0 \mathrm{~m}-3.0 \mathrm{~m}^{2} ; \mathrm{T} 3: 3.0 \times 1.5 \mathrm{~m}-4.5 \mathrm{~m}^{2}$ and T4: $3.0 \times 2.0 \mathrm{~m}-6.0 \mathrm{~m}^{2}$ ). Each experimental plot was represented by four planting lines with 7 plants, totaling 28 individuals, of which 10 were measured because a simple border was adopted.

Continuous forest inventory was realized at the ages of 24, 37, 48, 59 and 72 months. All individuals with a diameter at $1.30 \mathrm{~m}(\mathrm{DBH}) \geq 5 \mathrm{~cm}$ were inventoried, using mechanical caliper. Total Height $(\mathrm{H}, \mathrm{m})$ and Crown Insertion Height (CIH - height of the first live branch, characterized by leaves presence, $\mathrm{m}$ ) were taken with a Haglof electronic hypsometer. Crown Length (L, m) was calculated by difference between $\mathrm{H}$ and CIH, and the

FLORESTA, Curitiba, PR, v. 50, n. 3, p. 1633 - 1642, jul/set 2020.

Lafetá, B. O. et.al.

ISSN eletrônico 1982-4688

DOI: 10.5380/rf.v50 i3. 65255 
Crown Diameter $(C D, m)$, by the average of crown diameters, obtained from measurement of four radii in directions between planting lines and between plants through vertical projection of crown, using a metric tape.

The following morphometric indexes based on tree size and morphology, according to Sterba (1991) and Durlo and Denardi (1998), were evaluated: Crown Formal (CF), Slenderness Rate (SR), Range Index (RI), Salience Index (SI), Crown Proportion (CP) and Vital Space Index (VSI). Indexes were expressed as follows: $C F=C D / L ; S R=H / D B H ; R I=C D / H ; S I=C D / D B H ; C P=100 L / H$ e $V S I=C D^{2} / D B H^{2}$.

The indexes were subjected to Pearson's correlation analysis (r) with stem dimensions (DBH and $\mathrm{H}$ ) in the different planting spacings. The threshold for exclusion of variables was $|\mathrm{r}|<0.60$, following the premise that a correlation module above 0.6 represents a strong correlation (CAMPBELL, 2006). This procedure aimed to minimize problems regarding the accuracy loss of predictors.

\section{Modeling methods and evaluation}

Two modeling methods were tested to estimate crown morphometric indexes remaining $(|\mathrm{r}| \geq 0.60$ with stem dimensions), one by non-linear regression and other by SVM. Regression analysis was performed using Levenberg-Marquardt iterative method. For each planting spacing and crown index, three-parameter logistic model was adjusted using the most correlated stem dimension as a predictor variable, $Y=\alpha\left(1+\beta e^{-\gamma X}\right)^{-1}$, where $\alpha, \beta$ and $\gamma$ are logistic model parameters. DBH or height was chosen as predictor because it is conventionally analyzed in forest inventories.

The vector machines were constructed according to the statistical learning process described in detail by Vapnik (1995) and Meyer et al. (2017). SVM were implemented using the R “e1071" package (MEYER et al., 2017) and its default. For SVM training, four types of Kernel functions (linear, radial, sigmoid, and polynomial) were analyzed. Kernel functions are algorithms that improve computational power of learning machines, making it possible to represent phenomena of greater complexity. In order to obtain a generalized SVM with the ability to simultaneously estimate morphometric indexes in all planting spacings, numerical inputs were used. These were the most correlated stem dimension and the useful area per plant $\left(\mathrm{AU}, \mathrm{m}^{2}\right)$. Only one type of Kernel function was selected to compose the SVM in subsequent graphical analyses.

To compose the SVM for crown morphometric indexes estimation, the modeling method and the Kernel function selections were based on the mean absolute error (MAE), root mean square error (RMSE), and correlation coefficient ( $r$ ) between observed and estimated values. Adherence was assessed by the Kolmogorov-Smirnov test. In this test, the maximum difference between the cumulative distributions of errors is represented by the " $\mathrm{dn}$ " value. Graphical analyses consisted of statistical inspection of the dispersion of residues and standardized and observed values in relation to those estimated.

For the diagnosis of statistical effect, 1 and 5\% significance levels were used in all analyzes. These was performed with the aid of the Curve Expert 1.4 and R version 3.3 software (R CORE TEAM, 2017).

\section{RESULTS}

Significant negative correlation $(p \leq 0.01)$ of DBH was evidenced with all morphometric indexes. DBH showed greater variability of correlation between planting spacing when it was associated with crown formal $(|\mathrm{r}|$ $=0.17 \pm 0.12)$, range index $(|r|=0.50 \pm 0.16)$ and crown proportion $(|r|=0.38 \pm 0.17)$. Negative correlation was also observed for tree heights, except when associated to slenderness rate. Height correlations oscillated more in associations with slenderness rate $(|r|=0.21 \pm 0.19)$, followed by the crown formal $(|r|=0.31 \pm 0.19)$ and crown proportion $(|\mathrm{r}|=0.43 \pm 0.14)$.

In general, DBH and height had a relatively weak correlation with crown formal, slenderness rate and crown proportion (Table 1). Correlation between range index and height $(\mathrm{r}=-0.78 \pm 0.11, p \leq 0.01)$ was stronger than that with $\mathrm{DBH}(\mathrm{r}=-0.50 \pm 0.16, p \leq 0.01)$, varying little between planting spacing. On the other hand, salience and vital space indexes correlated better with DBH. Therefore, these last three morphometric indexes were selected for inter-dimensional relationship modeling.

Interdimensional relationships established were, range index as a function of height and salience, and vital space indexes, both depending on the DBH (Table 2). Absence of significant statistical effect by the Kolmogorov Smirnov test $(p>0.01)$ was verified in all equations generated to estimate morphometric indexes, except those linked to vital space index of the three least densified spacings $(\mathrm{dn}=0.33 \pm 0.07)$. Only the equation for estimating this index in $3.0 \times 0.5 \mathrm{~m}$ spacing showed a negative asymptote, represented by parameter $\alpha$. Regression modeling of salience and range indexes showed few deviations, with low values of MAE and RMSE. Significance of the correlation coefficients $(p \leq 0.01)$ was found in all adjustments. Estimates accuracy (Table 2) increased with the degree of association between variables (Table 1).

FLORESTA, Curitiba, PR, v. 50, n. 3, p. 1633 - 1642, jul/set 2020.

Lafetá, B. O. et.al.

ISSN eletrônico 1982-4688

DOI: $10.5380 /$ rf.v50 i3. 65255 
Table 1. Correlations of crown morphometric indexes of eucalypt trees with DBH and height, in different planting spacings.

Tabela 1. Correlações dos índices morfométricos da copa de árvores de eucalipto com o DAP e altura, em diferentes espaçamentos de plantio.

\begin{tabular}{|c|c|c|c|c|c|c|}
\hline Spacings & CF & SR & RI & SI & $\mathbf{C P}$ & VSI \\
\hline & & \multicolumn{5}{|c|}{ 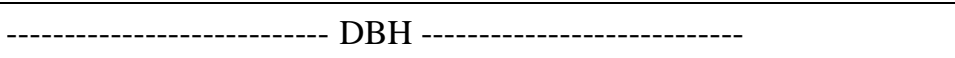 } \\
\hline $3.0 \times 0.5 \mathrm{~m}$ & $0.07^{\mathrm{ns}}$ & $-0.71^{* *}$ & $-0.26^{*}$ & $-0.76^{* *}$ & $-0.33^{* *}$ & $-0.69^{* *}$ \\
\hline $3.0 \times 1.0 \mathrm{~m}$ & $-0.11^{\mathrm{ns}}$ & $-0.33^{* *}$ & $-0.61^{* *}$ & $-0.77^{* *}$ & $-0.27^{*}$ & $-0.73^{* *}$ \\
\hline $3.0 \times 1.5 \mathrm{~m}$ & $-0.34^{* *}$ & $-0.53^{* *}$ & $-0.55^{* *}$ & $-0.83^{* *}$ & $-0.28^{* *}$ & $-0.74^{* *}$ \\
\hline \multirow[t]{2}{*}{$3.0 \times 2.0 \mathrm{~m}$} & $-0.18^{*}$ & $-0.28^{* *}$ & $-0.58^{* *}$ & $-0.78^{* *}$ & $-0.64^{* *}$ & $-0.72^{* *}$ \\
\hline & & \multicolumn{5}{|c|}{ 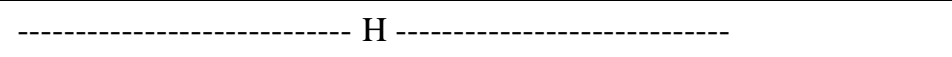 } \\
\hline $3.0 \times 0.5 \mathrm{~m}$ & $-0.11^{\mathrm{ns}}$ & $-0.06^{\mathrm{ns}}$ & $-0.64^{* *}$ & $-0.51^{* *}$ & $-0.31^{* *}$ & $-0.48^{* *}$ \\
\hline $3.0 \times 1.0 \mathrm{~m}$ & $-0.18^{\mathrm{ns}}$ & $0.25^{*}$ & $-0.78^{* *}$ & $-0.58^{* *}$ & $-0.33^{* *}$ & $-0.51^{* *}$ \\
\hline $3.0 \times 1.5 \mathrm{~m}$ & $-0.41^{* *}$ & $0.08^{\mathrm{ns}}$ & $-0.82^{* *}$ & $-0.72^{* *}$ & $-0.44^{* *}$ & $-0.63^{* *}$ \\
\hline $3.0 \times 2.0 \mathrm{~m}$ & $-0.53^{* *}$ & $0.46^{* *}$ & $-0.89^{* *}$ & $-0.79^{* *}$ & $-0.62^{* *}$ & $-0.76^{* *}$ \\
\hline
\end{tabular}

${ }^{*} p \leq 0.05 ;{ }^{* *} p \leq 0.01 ; \mathrm{CF}=$ crown formal; $\mathrm{SR}=$ slenderness rate; $\mathrm{RI}=$ range index; $\mathrm{SI}=$ salience index; $\mathrm{CP}=$ crown proportion; and $\mathrm{VSI}=$ vital space index. In bold are correlations equal or higher, in module, to 0.6 .

Table 2. Coefficients and adjustment quality of the logistic model for estimation of crown morphometric indexes of eucalypt trees as a function of DBH.

Tabela 2. Coeficientes e qualidade de ajuste do modelo logístico para a estimativa de índices morfométricos da copa de árvores de eucalipto em função do DAP.

\begin{tabular}{|c|c|c|c|c|c|c|}
\hline Spacings & $\alpha$ & $\boldsymbol{\beta}$ & $\gamma$ & MAE & RMSE & $\mathbf{r}$ \\
\hline \multicolumn{7}{|c|}{ 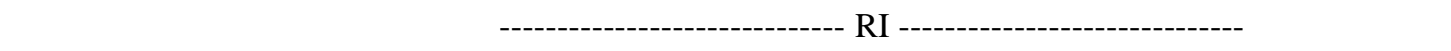 } \\
\hline $3.0 \times 0.5 \mathrm{~m}$ & 0.082 & -1.356 & 0.084 & 0.014 & 0.020 & $0.68^{* *}$ \\
\hline $3.0 \times 1.0 \mathrm{~m}$ & 0.071 & -1.043 & 0.047 & 0.014 & 0.023 & $0.84^{* *}$ \\
\hline $3.0 \times 1.5 \mathrm{~m}$ & 0.010 & -1.007 & 0.005 & 0.018 & 0.024 & $0.83^{* *}$ \\
\hline $3.0 \times 2.0 \mathrm{~m}$ & 0.002 & -1.005 & 0.001 & 0.018 & 0.024 & $0.91^{* *}$ \\
\hline \multicolumn{7}{|c|}{ 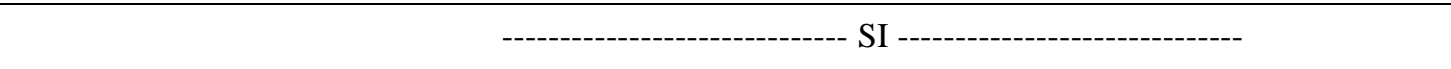 } \\
\hline $3.0 \times 0.5 \mathrm{~m}$ & 0.118 & -1.084 & 0.093 & 0.024 & 0.035 & $0.82^{* *}$ \\
\hline $3.0 \times 1.0 \mathrm{~m}$ & 0.084 & -1.006 & 0.047 & 0.024 & 0.034 & $0.83^{* *}$ \\
\hline $3.0 \times 1.5 \mathrm{~m}$ & 0.001 & -0.999 & 0.000 & 0.024 & 0.033 & $0.84^{* *}$ \\
\hline $3.0 \times 2.0 \mathrm{~m}$ & 0.002 & -1.001 & 0.001 & 0.026 & 0.035 & $0.80^{* *}$ \\
\hline \multicolumn{7}{|c|}{ 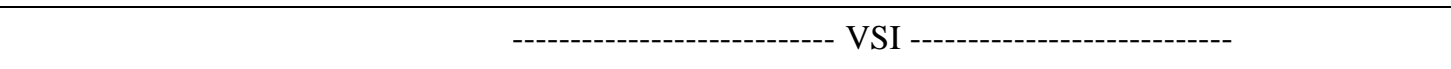 } \\
\hline $3.0 \times 0.5 \mathrm{~m}$ & -79.692 & -0.817 & -0.078 & 44.990 & 102.063 & $0.73^{* *}$ \\
\hline $3.0 \times 1.0 \mathrm{~m}$ & 2.108 & -1.014 & 0.003 & 43.655 & 104.725 & $0.66^{* *}$ \\
\hline $3.0 \times 1.5 \mathrm{~m}$ & 1.466 & -1.012 & 0.002 & 37.845 & 56.175 & $0.79^{* *}$ \\
\hline $3.0 \times 2.0 \mathrm{~m}$ & 3.012 & -1.047 & 0.006 & 33.812 & 46.629 & $0.78^{* *}$ \\
\hline
\end{tabular}

${ }^{* * *} p \leq 0.01 ; \mathrm{r}=$ correlation coefficient; $\mathrm{RI}=$ range index; $\mathrm{SI}=$ salience index; and VSI = vital space index. $\alpha, \beta$ and $\gamma$ are parameters of logistic model. Only functional relationship of range index used height as a predictor variable.

Among Kernel functions, radially based SVM performed better in terms of estimating morphometric indexes for different planting spacings (Table 3). Adherence adhesion $(p>0.01)$ was found in all vector machines with radial base Kernel functions, except for the range index in $3.0 \times 0.5 \mathrm{~m}$ spacing. SVM presented slightly better

FLORESTA, Curitiba, PR, v. 50, n. 3, p. 1633 - 1642, jul/set 2020.

Lafetá, B. O. et.al.

ISSN eletrônico 1982-4688

DOI: $10.5380 /$ rf.v50 i3. 65255 
predictive performance than regression for range and vital space indexes; quality was similar as to the salience index.

Table 3. Statistics of the approximation by support vector machines constructed for estimation of crown morphometric indexes of eucalypt trees as a function of DBH.

Tabela 3. Estatísticas das aproximações por máquinas vetor de suporte construídas para a estimativa de índices morfométricos da copa de árvores de eucalipto em função do DAP.

\begin{tabular}{|c|c|c|c|c|c|c|c|c|c|}
\hline \multirow{2}{*}{ Spacings } & \multicolumn{3}{|c|}{-------- RI -------- } & \multicolumn{3}{|c|}{-------- SI -------- } & \multicolumn{3}{|c|}{------- VSI ------- } \\
\hline & MAE & RMSE & $\mathbf{r}$ & MAE & RMSE & $\mathbf{r}$ & MAE & RMSE & $\mathbf{r}$ \\
\hline & \multicolumn{9}{|c|}{ 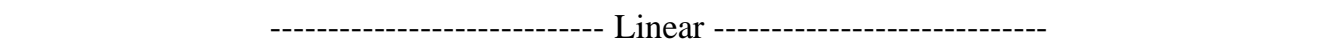 } \\
\hline $3.0 \times 0.5 \mathrm{~m}$ & 0.016 & 0.022 & $0.64^{* *}$ & 0.027 & 0.040 & $0.76^{* *}$ & 40.975 & 66.763 & $0.69^{* *}$ \\
\hline $3.0 \times 1.0 \mathrm{~m}$ & 0.018 & 0.023 & $0.78^{* *}$ & 0.029 & 0.040 & $0.77^{* *}$ & 38.949 & 57.616 & $0.73^{* *}$ \\
\hline $3.0 \times 1.5 \mathrm{~m}$ & 0.020 & 0.026 & $0.82^{* *}$ & 0.034 & 0.033 & $0.83^{* *}$ & 42.605 & 55.188 & $0.74^{* *}$ \\
\hline \multirow[t]{2}{*}{$3.0 \times 2.0 \mathrm{~m}$} & 0.025 & 0.035 & $0.89^{* *}$ & 0.027 & 0.036 & $0.78^{* *}$ & 33.855 & 52.383 & $0.72^{* *}$ \\
\hline & \multicolumn{9}{|c|}{ 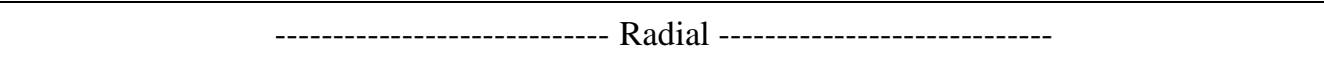 } \\
\hline $3.0 \times 0.5 \mathrm{~m}$ & 0.013 & 0.020 & $0.69^{* *}$ & 0.025 & 0.037 & $0.79^{* *}$ & 35.218 & 56.955 & $0.75^{* *}$ \\
\hline $3.0 \times 1.0 \mathrm{~m}$ & 0.013 & 0.018 & $0.85^{* *}$ & 0.024 & 0.035 & $0.83^{* *}$ & 31.310 & 47.144 & $0.81^{* *}$ \\
\hline $3.0 \times 1.5 \mathrm{~m}$ & 0.017 & 0.023 & $0.84^{* *}$ & 0.024 & 0.033 & $0.84^{* *}$ & 29.448 & 48.864 & $0.78^{* *}$ \\
\hline \multirow[t]{2}{*}{$3.0 \times 2.0 \mathrm{~m}$} & 0.017 & 0.023 & $0.92^{* *}$ & 0.025 & 0.035 & $0.80^{* *}$ & 27.720 & 44.118 & $0.80^{* *}$ \\
\hline & \multicolumn{9}{|c|}{------------------------ Sigmoid ----------------------- } \\
\hline $3.0 \times 0.5 \mathrm{~m}$ & 0.673 & 0.763 & $0.57^{* *}$ & 1.226 & 1.455 & $-0.74^{* *}$ & 1552.623 & 1843.910 & $-0.70^{* *}$ \\
\hline $3.0 \times 1.0 \mathrm{~m}$ & 0.406 & 0.491 & $0.33^{* *}$ & 0.434 & 0.517 & $<0.01^{\mathrm{ns}}$ & 557.002 & 667.965 & $-0.01^{\mathrm{ns}}$ \\
\hline $3.0 \times 1.5 \mathrm{~m}$ & 0.242 & 0.314 & $-0.59^{* *}$ & 0.522 & 0.623 & $0.77^{* *}$ & 684.152 & 818.425 & $0.75^{* *}$ \\
\hline \multirow[t]{2}{*}{$3.0 \times 2.0 \mathrm{~m}$} & 0.568 & 0.674 & $-0.03^{\mathrm{ns}}$ & 0.838 & 1.080 & $-0.66^{* *}$ & 1033.439 & 1342.115 & $-0.50^{* *}$ \\
\hline & \multicolumn{9}{|c|}{------------------------ Polynomial ----------------------- } \\
\hline $3.0 \times 0.5 \mathrm{~m}$ & 0.673 & 0.032 & $0.57^{* *}$ & 1.226 & 0.044 & $0.75^{* *}$ & 1552.623 & 68.688 & $0.65^{* *}$ \\
\hline $3.0 \times 1.0 \mathrm{~m}$ & 0.406 & 0.024 & $0.77^{* *}$ & 0.434 & 0.043 & $0.76^{* *}$ & 557.002 & 67.027 & $0.70^{* *}$ \\
\hline $3.0 \times 1.5 \mathrm{~m}$ & 0.242 & 0.028 & $0.82^{* *}$ & 0.522 & 0.043 & $0.72^{* *}$ & 684.152 & 65.422 & $0.66^{* *}$ \\
\hline $3.0 \times 2.0 \mathrm{~m}$ & 0.568 & 0.030 & $0.88^{* *}$ & 0.838 & 0.043 & $0.70^{* *}$ & 1033.439 & 55.157 & $0.67^{* *}$ \\
\hline
\end{tabular}

${ }^{* *} p \leq 0.01 ; \mathrm{r}=$ correlation coefficient; $\mathrm{RI}=$ range index; $\mathrm{SI}=$ salience index; and VSI = vital space index. Only functional relationship of range index used height as a predictor variable.

By adding values of dn statistic, the best modeling method was defined according to lowest "total dn". The predictive superiority of SVM (total $\mathrm{dn}=1.57$ ) in relation to logistic regression (total $\mathrm{dn}=2.14$ ) was proven. SVM concentrated standardized residues closest to the abscissa axis (Figure 1). In the graph of standardized residues of vital space index using logistic modeling, two estimates were removed for better visual interpretation (estimated VSI of 939.91 and 453.68 , with standardized residue of -4.08 and -0.31 , respectively), both belonging to $3.0 \times 1.0 \mathrm{~m}$ spacing. Morphometric indexes decreased sigmoidly with the increase of stem tree dimensions, tending to stabilization (Figure 2). 
Logistic
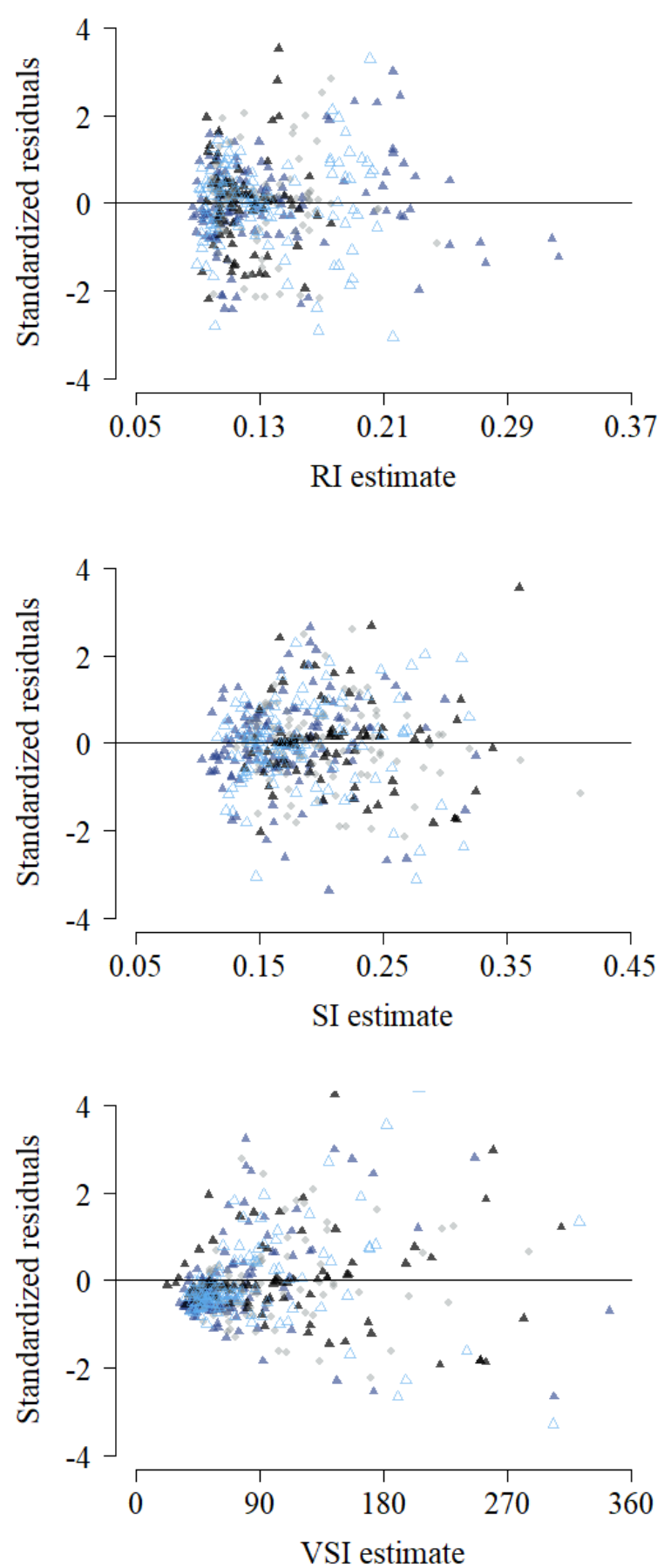

SVM
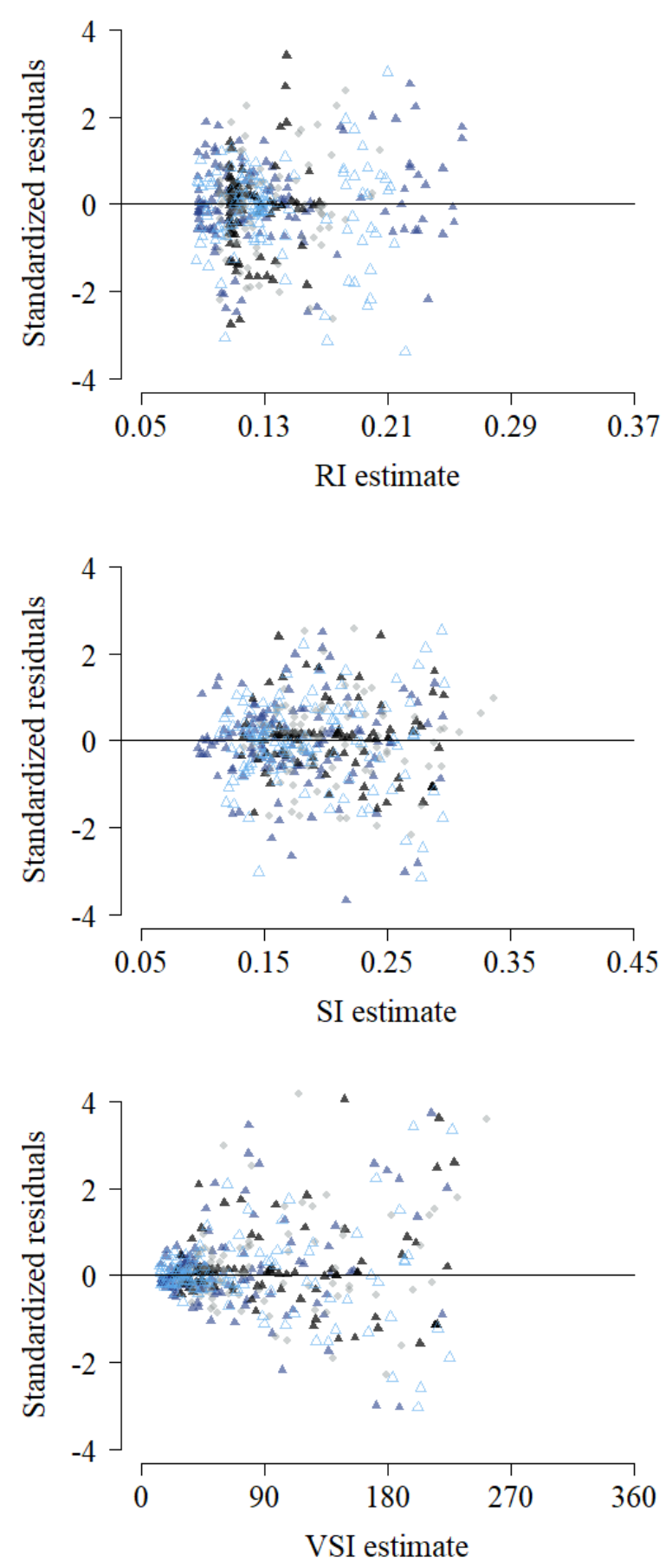

$$
\Delta 3,0 \times 0,5 \mathrm{~m} \quad 3,0 \times 1,0 \mathrm{~m} \triangle 3,0 \times 1,5 \mathrm{~m} \Delta 3,0 \times 2,0 \mathrm{~m}
$$

Figure 1. Standardized residue graphics generated from logistic model fitting to the left and support vector machines with radial base Kernel function to the right. RI = range index; $\mathrm{SI}=$ salience index; and VSI $=$ vital space index. 
Figura 1. Gráficos de resíduos padronizados gerados a partir do ajuste do modelo logístico à esquerda e máquinas vetor de suporte com função Kernel de base radial à direita. RI = índice de abrangência; SI = índice de saliência; e VSI = índice de espaço vital.

\section{Logistic}
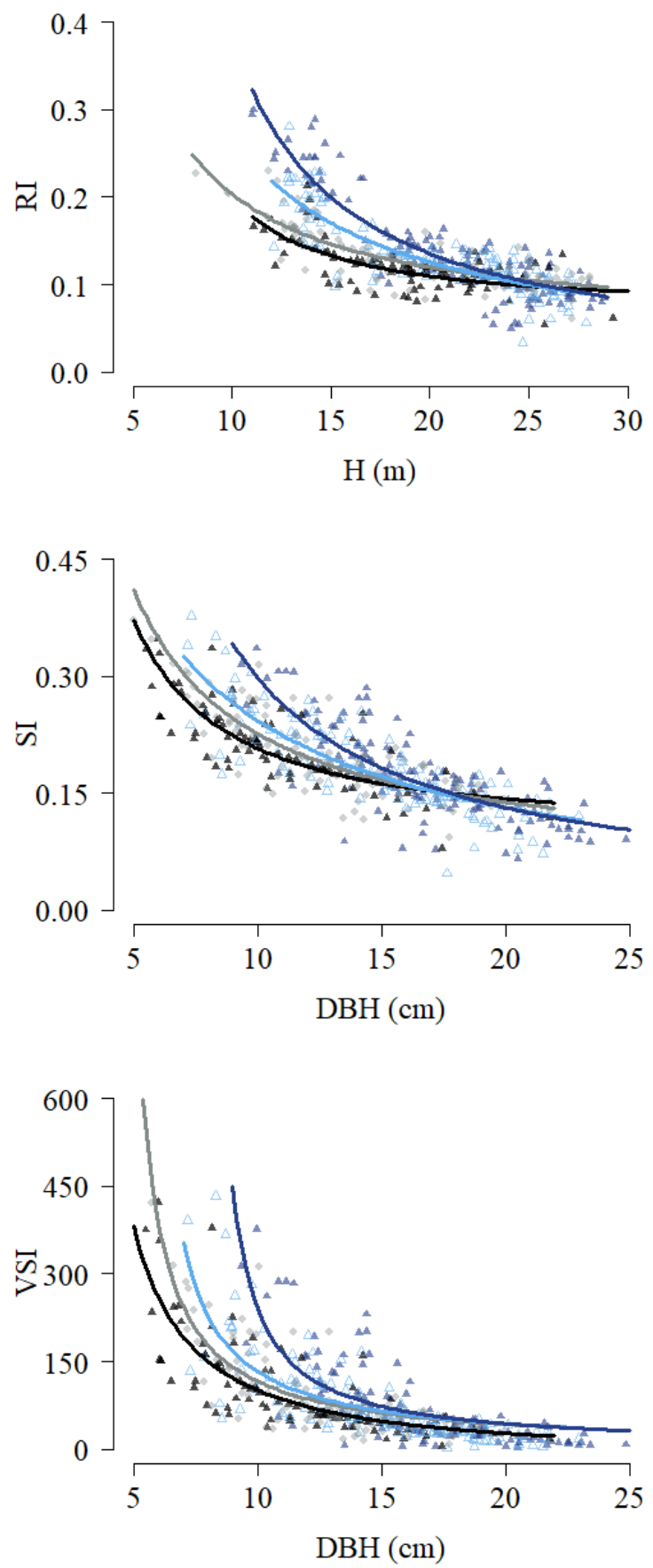

SVM
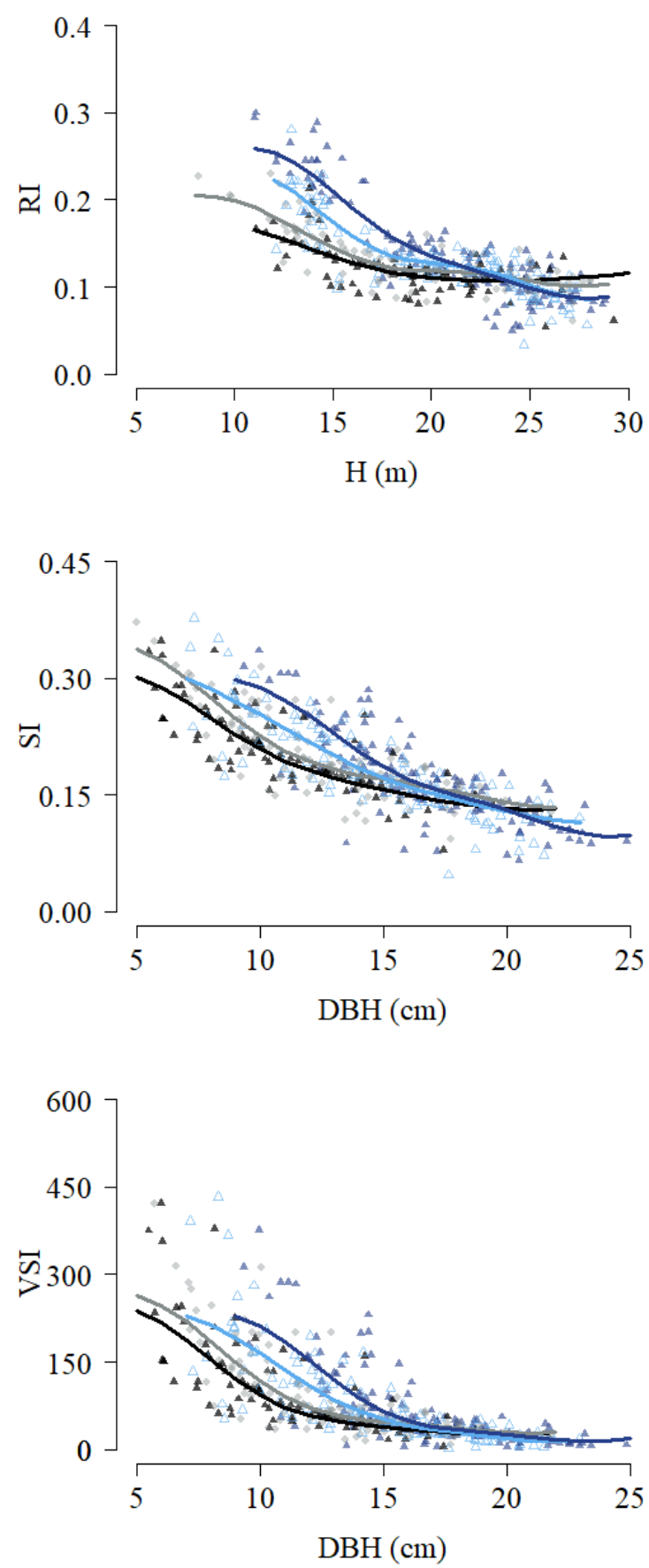

$\Delta 3,0 \times 0,5 \mathrm{~m} \quad 3,0 \times 1,0 \mathrm{~m} \triangle 3,0 \times 1,5 \mathrm{~m} \triangle 3,0 \times 2,0 \mathrm{~m}$

Figure 2. Observed values and curves generated for crown morphometric indexes of eucalypt trees in different planting spacings. Curves obtained with logistic model adjustment to the left and curves from support

FLORESTA, Curitiba, PR, v. 50, n. 3, p. 1633 - 1642, jul/set 2020. 
vector machines with radial base Kernel function to the right. RI = range index; SI = salience index; and VSI = vital space index.

Figura 2. Valores observados e curvas geradas para os índices morfométricos da copa de árvores de eucalipto em diferentes espaçamentos de plantio. Curvas obtidas com o ajuste do modelo logístico à esquerda e curvas oriundas de máquinas vetor de suporte com função Kernel de base radial à direita. RI = índice de abrangência; SI = índice de saliência; e VSI = índice de espaço vital.

\section{DISCUSSION}

Interdimensional relations were defined for three crown morphometric indexes estimations, which showed strong correlation with stem dimensions. Range index correlated more with height, while salience and vital space had a better association with DBH (Table 1). This was probably due to the inclusion of respective stem dimensions in respective mathematical expressions of the indexes. Use of predictors correlated with indexes was essential for predictive quality of the modeling methods.

As a consequence of wide crown phenotypic plasticity that eucalypt can assume in scenarios with different planting densities and ages (FORRESTER et al., 2012; WINK et al., 2012; COBLE et al., 2014; SAPIJANSKAS et al., 2014 ; VAN DE PEER et al., 2017), range and salience indexes were estimated satisfactorily by logistic regression (Table 2). However, equations estimates of the vital space index were biased (Figure 1).

Negative asymptote of the equation that outlines the vital space index in $3.0 \times 0.5 \mathrm{~m}$ spacing was an indication of the inability to represent biological behavior of thicker stems. From a statistical point of view, it is expected that quadratic relationships between crown diameter and DBH are always greater than zero. Still on this index, in the three widest spacing, lack of adherence of the estimates to the observations can be confirmed visually, in Figures 1 and 2, with MAE and RMSE values much higher than those pertinent to the SVM with radial base Kernel function (Tables 2 and 3). It should be noted that vital space index differs from the index of salience in view of the greater weight it provides to the largest diameters.

The use of the radial base Kernel function improved SVM performance, and presented a considerable gain in precision when compared to the sigmoid and polynomial functions. This difference is evident when analyzing the statistics in Table 3. Such progress in predictive quality is in line with what has been reported in several studies involving use of Kernel functions for solving highly complex problems (GHITESCU et al., 2017; SILVA et al., 2017b).

According to Silva et al. (2017b), computational efficiency, simplicity and adaptation for optimization are characteristics that favor SVM implementation with radial based Kernel function. Although range index estimates $(3.0 \times 0.5 \mathrm{~m})$ with application of these SVM showed lack of adherence by the Kolmogorov-Smirnov test, there was no marked loss of predictive quality (Figures 1). MAE and RMSE statistics did not contrast with those related to those of the other spacings, being lower than those obtained with logistic model adjustments.

Figure 2 curves showed that both modeling methods established interdimensional relationships with biological realism, with a clear decrease in tendency of range, salience and vital space indexes with increased stem dimensions. This is a decrease confirmed by the negative and significant values $(p \leq 0.01)$ of correlation coefficients (Table 1). Diameter and height growth of stems contributed to morphometric indexes reduction. Indexes values decrease was also observed by Wink et al. (2012) in homogeneous eucalypt forest plantations with 20, 44 and 240 months of age.

In view of the above-mentioned difficulty in establishing interdimensional relations with crown eucalypt, modeling methods presented relatively few outliers (standardized residues outside the range of -3 to 3) (Figure 1). Smaller stems had more dispersed residues. The predictive quality of the modeling methods was not influenced by the outliers' presence, except for the vital space index modeling with logistic regression.

Modeling methods discriminated planting spacing, describing morphological changes with eucalypt stems growth (Figure 2). Smaller stems exhibited higher morphometric indexes in wide spacing. Difference in indexes between spacing reduced with stems size increase. Planting density intensification impaired lateral expansion of trees and anticipated the contact between crowns. This contact between plants is an indication of competition establishment for light in forest ecosystems (VAN DE PEER et al., 2017). According to Padoin and Finger (2010), space competition with adjacent trees over time promotes a reduction in diameter and crown projection area, corroborating with field measurements.

Crown diameter of the largest stems oscillates little between spacings. Proportionally narrower crowns are related to the larger stems. A proportion between crown projection area and sectional area (represented by the vital space index) indicated an increasing competition for space, especially in the densest spacings. Decrease in the morphometric indices analyzed with stem dimensions increase indicates thinning need in stands forest (SILVA

FLORESTA, Curitiba, PR, v. 50, n. 3, p. 1633 - 1642, jul/set 2020.

Lafetá, B. O. et.al.

ISSN eletrônico 1982-4688

DOI: $10.5380 /$ rf.v50 i3. 65255 
et al., 2017a). Thinning definition can be performed with help of crown morphometric indexes for selection of suppressed and intermediate trees.

SVM application with radial base Kernel function to morphometric indexes estimates, simultaneously in different planting spacing, presented a predictive performance superior to logistic regression. This difference is of great practical importance because, although use of logistic equations is simpler, it requires a longer time to adjust and obtain parameters, as well as their storage and application. In the present work, 12 equations were generated to be examined individually. In contrast there were three SVM generated with radial base Kernel function, one per crown morphometric index. It is noteworthy that a constant checking of morphometric indexes values is necessary, because variations can occur for the same genotype depending of edaphic and climatic conditions (COBLE et al., 2014; SAPIJANSKAS et al., 2014).

SVM demonstrated the ability to represent biological information in different scenarios of spatial competition. Therefore, promising to reduce sampling effort in crown surveys in forest inventories and increase of estimate accuracy. Results obtained provide subsidies for future research development about inter-dimensional morphometric relationships modeling of tree crown. Modeling proved to be an efficient statistical technique capable of indirectly representing morphometric indexes based on routine field measurements, such as DBH and height.

Forest management success depends of the quality and quantity of information available. Forest sector interest in use of computational intelligence coupled with applicability of inter-dimensional morphometric relationships modeling of tree crown contribute to foundation of silvicultural decisions and understanding of growth dynamics in even-aged stands. It is important to note that difficulties in adjusting non-linear models or SVM have been solved due to technological advances in information technology, making parameterization increasingly simpler and facilitating choice of the best modeling method.

\section{CONCLUSIONS}

- Support vector machines modeling with radial Kernel function can be used with good precision to morphometric indexes estimate of eucalypt tree crowns simultaneously for different planting spacing.

- Support vector machine technique can be recommended to predict the range, salience and vital space indexes, related to eucalypt tree crowns, using DBH and useful area per plant in the set of predictor variables.

- Dendrometric predictor variables combination and useful area can be a viable alternative to improve quality of morphometric indexes estimates.

- Logistic model was satisfactorily adapted to the problem, more specifically in range and salience indexes prediction of eucalypt trees.

\section{REFERENCES}

CAMPBELL, M. J. Statistics at square two: understanding modern statistical applications in medicine. 2. ed. London: BMJ Books - Blackwell Publishing, 2006. 144p.

CARVAlHO, S. P. C.; CALEGARIO, N.; SilvA, F. F.; BORGES, L. A. C.; MENDONÇA, A. R.; LIMA, M. P. Modelos não lineares generalizados aplicados na predição da área basal e volume de Eucalyptus clonal. Cerne, Lavras, v. 17, n. 4, p. 541-548, 2011.

CERQUEIRA, C. L.; MÔRA, R.; TONINI, H. Forma do fuste de eucalipto em diferentes arranjos de plantio e espaçamentos. Advances in Forestry Science, Cuiabá, v. 4, n. 3, p. 137-141, 2017.

COBLE, A. P.; AUTIO, A.; CAVALIERI, M. A.; BINKLEY, D.; RYAN, M. G. Converging patterns of vertical variability in leaf morphology and nitrogen across seven Eucalyptus plantations in Brazil and Hawaii, USA. Trees, Berna, v. 28, p. 1-15, 2014.

DIONISIO, L. F. S.; CONDÉ, T. M.; GOMES, J. P.; MARTINS, W. B. R.; SILVA, M. W.; SILVA, M. T. Caracterização morfométrica de árvores solitárias de Bertholletia excelsa H. B. K. no sudeste de Roraima. Revista Agroambiente On-line, Boa Vista, v. 11, n. 2, p. 163-173, 2017.

DURLO, M. A.; DENARDI, L. Morfometria de Cabralea canjerana, em mata secundária nativa do Rio Grande do Sul. Ciência Florestal, Santa Maria, v. 8, n. 1, p. 55-66, 1998.

FEY, R.; MAlAVASI, U. C.; MALAVASI, M. M.; SCHUlZ, D. G.; DRANSKI, J. A. L. Relações interdimensionais e produtividade de pinhão-manso (Jatropha curcas L.) em sistema silvipastoril. Semina, Londrina, v. 35, n. 2, p. 613-624, 2014.

FLORESTA, Curitiba, PR, v. 50, n. 3, p. 1633 - 1642, jul/set 2020.

Lafetá, B. O. et.al.

ISSN eletrônico 1982-4688

DOI: $10.5380 /$ rf.v50 i3. 65255 
FORRESTER, D. I.; CALLOPY, J. J.; BEADLE, C. L.; BAKER, T. G. Interactive effects of simultaneously applied thinning, pruning and fertilizer application treatments on growth, biomass production and crown architecture in a young Eucalyptus nitens plantation. Forest Ecology and Management, Amsterdam, v. 267, p. 104-116, 2012.

GHITESCU, R.; CURTEANU, S.; MIHAILESCU, C.; VOLF, I.; LEON, F.; GILCA, A. I.; POPA, V. I. Support vector machine combined with genetic algorithm for optimization of microwave-assisted extraction of polyphenols from spruce wood bark. Cellulose Chemistry and Technology, Bucareste, v. 51, n. 3-4, p. 203-213, 2017.

HOLM, S.; NELSON, R.; STÅHL, G. Hybrid three-phase estimators for large-area forest inventory using ground plots, airbone LiDAR and space LiDAR. Remote Sensing of Environment, New York, v. 197, p. 85-97, 2017.

MElO, E. A.; CALEGARIO, N.; MENDONÇA, A. R.; POSSATO, E. L.; ALVES, J. A.; ISAAC JÚNIOR, M. A. Modelagem não linear da relação hipsométrica e do crescimento das árvores dominantes e codominantes de Eucalyptus sp. Ciência Florestal, Santa Maria, v. 27, n. 4, p. 1325-1338, 2017.

MENDONÇA, A. R.; CALEGARIO, N.; SILVA, G. F.; SOUZA, A. L.; TRUGILHO, P. F.; CARVALHO, S. P. C.; POSSATO, E. L. Modelagem da produção de sortimentos em povoamento de eucalipto. Cerne, Lavras, v. 20, n. 4, p. 587-594, 2014.

MEYER, D.; DIMITRIADOU, E.; HORNIK, K.; WEINGESSEL, A.; LEISCH, F.; CHANG, C.; LIN. C. e1071: Misc Functions of the Department of Statistics, Probability Theory Group (Formerly: E1071), TU Wien. R package version 1.6-8, 2017.

PADOIN, V.; FINGER, C. A. G. Relações entre as dimensões da copa e a altura das árvores dominantes em povoamento de Pinus taeda L. Ciência Florestal, Santa Maria, v. 20, n.1 p. 95-105, 2010.

R CORE TEAM. R: A language and environment for statistical computing. Vienna: R Foundation for Statistical Computing. 2017.

ROMAN, M.; BRESSAN, D. A.; DURLO, M. A. Variáveis morfométricas e relações interdimensionais para Cordia trichotoma (Vell.) Arráb. Ex Steud. Ciência Florestal, Santa Maria, v. 19, n. 4, p. 473-480, 2009.

SAPIJANSKAS, J.; PAQUETTE, A.; POTVIN, C.; KUNERT, N.; LOREAU, M. Tropical tree diversity enhances light capture through crown plasticity and spatial and temporal niche differences. Ecology, Amsterdam, v. 25, n. 9, p. 2479-2492, 2014.

SEIDEL, D.; RUZICKA, K.; PUETTMANN, K. Canopy gaps the shade of Douglas-fir crowns in the western Cascades, Oregon. Forest Ecology and Management, Amsterdam, v. 363, p. 31-38, 2016.

SILVA, F. A.; FORTES, F. O.; RIVA, D.; SCHORR, L. P. B. Caracterização de índices morfométricos para Araucaria angustifólia plantada na região norte do Rio Grande do Sul. Advances in Forestry Science, Cuiabá, v. 4, n. 3, p. 143-146, 2017a.

SILVA, M. B. P.; ESCOBEDO, J. F.; SANTOS, C. M.; ROSSI, T. J.; SILVA, S. H. M. G. Performance of the Angstrom-Prescott Model (A-P) and SVM and ANN techniques to estimate the daily global solar irradiation in Botucatu/SP/Brazil. Journal of Atmospheric and solar-terrestrial physics, Amsterdam, v. 160, p. 11-23, 2017b.

STABEN, G. W.; LUCIEER, A.; EVANS, K. G.; SCARTH, P.; COOK, G. D. Obtaining biophysical measurements of wood vegetation from high resolution digital aerial photography in tropical and arid environments: Northern Territory, Australia. International Journal of Applied Earth Observation and Geoinformation, Amsterdam, v. 52, p. 204-220, 2016.

STERBA, H. Forstliche Ertragslehre. Wien: Universität für Bodenkultur, 1991. 160p.

VAN DE PEER, T.; VERHEYEN, K.; KINT, V.; VAN CLEEMPUT, E.; MUYS, B. Plasticity of tree architecture through interspecific and intraspecific competition in a young experimental plantation. Forest Ecology and Management, Amsterdam, v. 385, p. 1-9, 2017.

VAPNIK, V. N. The nature of statistical learning theory. New York: Springer-Verlag, 1995. 188p.

WINK, C.; MONTEIRO, J, S.; REINERT, D. J.; LIBERALESSO, E. Parâmetros da copa e a sua relação com diâmetro e altura das árvores de eucalipto em diferentes idades. Scientia Forestalis, Piracicaba, v. 40, n. 93, p. 57-67, 2012.

FLORESTA, Curitiba, PR, v. 50, n. 3, p. 1633 - 1642, jul/set 2020.

Lafetá, B. O. et.al.

ISSN eletrônico 1982-4688

DOI: $10.5380 /$ rf.v50 i3. 65255 